\title{
Pre-weaning Growth of Etawah Grade and Etawah Grade x Bligon kids
}

\author{
Adi Tiya Warman ${ }^{1}$, Restyana Whigiska Sari ${ }^{1}$, Bayu Andri Atmoko ${ }^{1}$, Nono \\ Ngadiyono $^{1}$ and I Gede Suparta Budisatria ${ }^{1, *}$ \\ ${ }^{1}$ Department of Animal Production, Faculty of Animal Science, Universitas Gadjah Mada. Jl. Fauna No 3, Kampus \\ UGM, Bulaksumur, Yogyakarta, Indonesia. 55281 \\ ${ }^{*}$ Corresponding author. Email: budisatria@ugm.ac.id
}

\begin{abstract}
This study aims to determine the growth of Etawah Grade and Etawah Grade x Bligon kids during the pre-weaning period. A total of 13 kids consisted of 6 Etawah Grade kids and 7 Etawah Grade $x$ Bligon kids with single type birth were observed. The birth weight and weaning weight, average daily gain (ADG), the gain of body size, and milk consumption of kids were collected and measured monthly during the pre-weaning period ( 3 months). The body size variable consisted of body length, body height, hip height, chest width, hip width, chest girth, head length, head width and ear length. All the variables were analyzed using the independent sample T-test. The statistical analysis indicated no significant difference in all variables except the gain of hip width $(\mathrm{P}<0.05)$. The gain of hip width on Etawah Grade and Etawah Grade $x$ Bligon were 3.42 \pm 1.02 and $4.79 \pm 0.81 \mathrm{~cm}$ respectively. Birth weight, weaning weight, and ADG of Etawah Grade and Etawah Grade $x$ Bligon kids were $2.94 \pm 0.48$ and $2.97 \pm 0.35 \mathrm{~kg} ; 9.65 \pm 1.69$ and $9.78 \pm 2.44 \mathrm{~kg}$; $0.07 \pm 0.16$ and $0.08 \pm 0.26 \mathrm{~kg} / \mathrm{head} /$ day, respectively. Milk consumption of Etawah Grade and Etawah Grade x Bligon kids was decreased in a row form the first, second and third month, which were $0.78 \pm 0.15$ and $0.72 \pm 0.16 ; 0.61 \pm 0.11$ and $0.56 \pm 0.07 ; 0.42 \pm 0.15 \pm 0.43 \pm 0.18 \mathrm{~kg} / \mathrm{head} /$ day, respectively. In conclusion, the growth of Etawah Grade and Etawah Grade $\mathrm{x}$ Bligon kids during the pre-weaning period was similar.
\end{abstract}

Keywords: Bligon goat, crossbreeding, Etawah Grade goat, pre-weaning period, productivity.

\section{INTRODUCTION}

Goats played a vital role for smallholder farmers in the Indonesian agricultural system. The goat population in Indonesia was increased in 2016-2017, from 17.86 to 18.20 million [1]. According to Budisatria and Udo [2], goats have a reasonably high economic value, which plays a role in socio-cultural aspects and religious celebrations. Goats were able to adapt to the climate in Indonesia, and their development did not require a large area. Even though the goat population is relatively encouraging, it still needs to be improved in livestock production. Indonesia has diverse genetic resources of goats, which are spread in almost all regions in Indonesia. The domestic goat in Indonesia was estimated to come from a similar ancestor, namely the Kacang goat. All local goat breeds refer to the Kacang goat characteristics and have adapted to the environment in their developing areas [3]. The local goat breeds widely developed in Indonesia were the Etawah Grade (PE) and the Bligon goat, especially on Java Island. PE goats were crossbreeding between Kacang goats with Jamnapari goats or Etawah goats imported from India [4]. The Bligon goat was also a local goat that many farmers were currently keeping. Bligon goat was used for crossbreeding from local goats (Kacang goats) with PE goat [5]. The two breeds of goats have diverse and different characteristics and productivity.

Productivity in the goat production system was very influential on the livestock population. Productivity was the result of an animal at a specific time expressed by growth and reproduction. Growth was a change in size, including body weight, body size, and composition [6]. The pre-weaning growth of goats can be influenced by several factors, namely litter size, sex ratio, birth weight, milk consumption, weaning weight, daily body weight gain, and body size $[7,8]$. PE and Bligon goats were very popular and widely developed by smallholder farmers in Central Java and Yogyakarta. Crosses between PE and 
Bligon goats have been designed to improve local goats' genetic quality. Considering the close origin of the two breeds, they came from the same parent, so their productivity is interesting to study, especially in preweaning growth. Many studies on the pre-weaning growth of the two goat breeds have been carried out separately on the scale of smallholder farms (on-farm research) on PE goats $[9,10]$ and Bligon goats $[5,11]$. The previous study was carried out with various characteristics of livestock and maintenance conditions, so the results were quite varied. The research of PE and Bligon goats under similar environmental conditions and maintenance systems (on-laboratory research) needs to be done to optimize their genetic expression and potential. Therefore, this study aims to determine the growth of Etawah Grade and Etawah Grade $\mathrm{x}$ Bligon kids during the pre-weaning period.

\section{MATERIAL AND METHODS}

The study was conducted at Unit Pelaksana Teknis (UPT) of the Faculty of Animal Science, Universitas Gadjah Mada, for five months, starting from June to October 2019. A total of 13 kids consisted of Six PE kids and seven PE $x$ Bligon kids were observed. The kids were obtained from the single birth type from six PE and seven Bligon does. The kids were kept with their parents in individual pens $(1 \times 1,5 \mathrm{~m})$ during three months (weaning) with similar conditions and management. The feed was given twice a day in the morning (08.00) and evening (14.00) with concentrate feed (60\%) and elephant grass (40\%), water was provided adlibitum. The feed was done based on $10 \%$ body weight (fresh feed). Feed and nutrients intake was shown in Table 1.

Table 1. Feed and nutrients intake of PE and Bligon does

\begin{tabular}{|l|l|l|}
\hline \multirow{2}{*}{$\begin{array}{c}\text { Feed and nutrients intake of } \\
\text { does }\end{array}$} & \multicolumn{2}{|c|}{ Breed } \\
\cline { 2 - 3 } & $\begin{array}{l}\text { Etawah } \\
\text { Grade }\end{array}$ & Bligon \\
\hline Concentrate $(\mathrm{kg})$ & $0.94 \pm 0.10$ & $1.00 \pm 0.14$ \\
\hline Elephant grass $(\mathrm{kg})$ & $1.23 \pm 0.26$ & $1.00 \pm 0.26$ \\
\hline Total $(\mathrm{kg})$ & $2.17 \pm 0.36$ & $2.00 \pm 0.40$ \\
\hline DM intake (kg/head/day) & $1.02 \pm 0.26$ & $1.05 \pm 0.15$ \\
\hline CP intake (kg/head/day) & $0.17 \pm 0.01$ & $0.18 \pm 0.02$ \\
\hline TDN $(\mathrm{kg} / \mathrm{head} /$ day) & $0.62 \pm 0.06$ & $0.64 \pm 0.09$ \\
\hline
\end{tabular}

$\mathrm{DM}=$ dry matter, $\mathrm{CP}=$ crude protein, $\mathrm{TDN}=$ total digestible nutrient

The kids were weighed with a WeiHeng@ $\bigodot$ weight scale (capacity of $50 \mathrm{~kg}$ with an accuracy of $0.001 \mathrm{~kg}$ ) and the body size was measured with a FHK@ ruler (accuracy of $0.01 \mathrm{~cm}$ ). Feed samples were weighed with an SF400@ digital scale (capacity of $10 \mathrm{~kg}$ and an accuracy of $0.001 \mathrm{~kg}$ ). The birth weight and weaning weight, average daily gain (ADG), the gain of body size, and milk consumption of kids were collected and measured monthly during the pre-weaning period (3 months). The body size variable consisted of body length, body height, hip height, chest width, hip width, chest girth, head length, head width, and ear length. All the variables were analyzed using the independent sample Ttest by Statistical Product and Service Solutions (SPSS) version 25 .

\section{RESULTS AND DISCUSSION}

Pre-weaning growth of goat expressed by gain and increased of body weight and body sizes. The body weight, weaning weight, ADG, and the gain of body size of Etawah Grade and Etawah Grade x Bligon kids were presented in Table 2 . The statistical analysis indicated no significant difference in all variables except the gain of hip width $(\mathrm{P}<0.05)$. The increase of hip width on $\mathrm{PE}$ and PE $x$ Bligon kids were $3.42 \pm 1.02$ and $4.79 \pm 0.81 \mathrm{~cm}$, respectively. The birth weight, weaning weight, ADG of Etawah Grade and Etawah Grade $\mathrm{x}$ Bligon were $2.94 \pm 0.48$ and $2.97 \pm 0.35 \mathrm{~kg} ; 9.65 \pm 1.69$ and $9.78 \pm 2.44$ $\mathrm{kg} ; 0.07 \pm 0.16$ and $0.08 \pm 0.26 \mathrm{~kg} / \mathrm{head} /$ day, respectively.

The results were lower than the birth weight of PE kids in previous studies with a single birth type by Budisatria et al [8] was $3.13 \mathrm{~kg}$, however higher than Destomo et al [12] was $2.76 \mathrm{~kg}$. In this study, the PE $\mathrm{x}$ Bligon kids had a higher birth weight than a previous study by Budisatria et al [5] was $2.15 \mathrm{~kg}$. The weaning weight of the PE kids was higher than a previous study by Zurahman [10] was $9.09 \pm 1.77 \mathrm{~kg}$. However, smaller than a previous study by Budisatria et al [8] was 14.21 $\mathrm{kg}$. The weaning weight of PE $\mathrm{x}$ Bligon kids was higher than a previous study by Budisatria et al [5] was $8.65 \mathrm{~kg}$. The ADG was obtained in this study was smaller than a previous study by Budisatria et al [8] ADG of PE kids for 90 days was $89.00-106.88 \mathrm{~g} / \mathrm{head} /$ day. However, it was higher than the Budisatria et al [5] study, which reported that ADG of male and female Bligon kids was $64.50 \pm$ 18.13 and $75.70 \pm 20.92 \mathrm{~g} / \mathrm{head} /$ day, respectively.

In this study, the gain in body size of Etawah Grade and Etawah Grade x Bligon kids were not significantly different. Several body sizes were positively correlated with livestock body weight. The body length and chest girth had $77.6 \%$ accuracy in predicting body weight [13]. So that in this study, the gain in body weight that was not different was also followed by the gain in body weight that was not different. Body height, chest width, chest girth, hip height, hip width and body length of Etawah Grade $x$ Bligon kids at the weaning (90 days) were $42.50 \pm 2.17 ; \quad 11.20 \pm 2.21 ; \quad 46.00 \pm 1.54 ; \quad 47.40 \pm 3.27$; $6.80 \pm 0.27$, and $41.60 \pm 1.73 \mathrm{~cm}$, respectively [11].

The pre-weaning growth of kids obtained with the different goat breed in this study was not significantly different due to birth weight, birth type and milk consumption factors. The similar birth weight, single birth type, and milk consumption of kids from the does 
Table 2. Body weight, waening weight, average daily gain and gain of body sizes of Etawah Grade and Etawah Grade $\mathrm{x}$ Bligon kids

\begin{tabular}{|c|c|c|}
\hline \multirow[b]{2}{*}{ Variables } & \multicolumn{2}{|l|}{ Breed } \\
\hline & Etawah Grade & $\begin{array}{l}\text { Etawah Grade x } \\
\text { Bligon }\end{array}$ \\
\hline Birth weight $(\mathrm{kg})^{\mathrm{ns}}$ & $2.94 \pm 0.48$ & $2.97 \pm 0.35$ \\
\hline Weaning weight $(\mathrm{kg})^{\mathrm{ns}}$ & $9.65 \pm 1.69$ & $9.78 \pm 2.44$ \\
\hline Average daily gain (kg/head/day) ns & $0.07 \pm 0.16$ & $0.08 \pm 0.26$ \\
\hline \multicolumn{3}{|l|}{ Gain of body sizes } \\
\hline Body length $(\mathrm{cm})^{\mathrm{ns}}$ & $20.33 \pm 1.63$ & $21.00 \pm 3.79$ \\
\hline Body height $(\mathrm{cm})^{\text {ns }}$ & $17.50 \pm 3.27$ & $16.71 \pm 2.50$ \\
\hline Hip height $(\mathrm{cm})^{\mathrm{ns}}$ & $16.83 \pm 2.06$ & $18.14 \pm 2.12$ \\
\hline Chest width $(\mathrm{cm})^{\mathrm{ns}}$ & $5.50 \pm 1.64$ & $7.14 \pm 1.68$ \\
\hline Hip width $(\mathrm{cm})^{\mathrm{ns}}$ & $3.42 \pm 1.02^{\mathrm{a}}$ & $4.79 \pm 0.81^{b}$ \\
\hline Chest girth $(\mathrm{cm})^{\mathrm{ns}}$ & $15.83 \pm 2.48$ & $15.93 \pm 2.46$ \\
\hline Head length $(\mathrm{cm})^{\mathrm{ns}}$ & $4.83 \pm 1.94$ & $3.71 \pm 1.38$ \\
\hline Head width $(\mathrm{cm})^{\text {ns }}$ & $3.67 \pm 1.21$ & $3.85 \pm 0.69$ \\
\hline Ear length $(\mathrm{cm})^{\mathrm{ns}}$ & $7.33 \pm 1.63$ & $7.71 \pm 4.39$ \\
\hline
\end{tabular}

a,b diferent superscripts in the same line showed a significant different $(\mathrm{P}<0.05),{ }^{\mathrm{ns}}$ Non-significant

that received similar nutrient intake resulted in similar pre-weaning growth. This assumption was in line with the Zurahman [10], who stated that pre-weaning growth in goats was varied and depended on genetic, weaning age and maintenance management, especially aspects of feeding, which significantly affect the ability of the does to produce milk during the pre-weaning period. Several studies indicated the influence of non-genetic factors, which include the litter size, gender, and age of the goat on birth and weaning weight, ADG, and weaning natality [14].

Milk consumption is one of the essential factors in pre-weaning growth kids [8]. In addition to affecting the growth and development of kids, milk consumption can also affect the mortality of kids during the pre-weaning period. Milk consumption of Etawah Grade and Etawah Grade x Bligon kids were presented in Table 3.

Table 3. Milk consumption of Etawah Grade and Etawah Grade x Bligon kids

\begin{tabular}{|c|c|c|}
\hline \multirow{2}{*}{$\begin{array}{l}\text { Feed and } \\
\text { nutrients intake of } \\
\text { does }\end{array}$} & \multicolumn{2}{|l|}{ Breed } \\
\hline & Etawah Grade & $\begin{array}{l}\text { Etawah Grade } \\
\text { x Bligon }\end{array}$ \\
\hline $\begin{array}{l}\text { First month } \\
(\mathrm{kg} / \text { head/day })\end{array}$ & $0.78 \pm 0.15$ & $0.72 \pm 0.16$ \\
\hline $\begin{array}{l}\text { Second month } \\
\text { (kg/head/day) }{ }^{\mathrm{ns}}\end{array}$ & $0.61 \pm 0.11$ & $0.56 \pm 0.07$ \\
\hline $\begin{array}{l}\text { Third month } \\
\text { (kg/head/day) ns }\end{array}$ & $0.42 \pm 0.15$ & $0.43 \pm 0.18$ \\
\hline $\begin{array}{l}\text { Average } \\
\text { (kg/head/day) ns }\end{array}$ & $0.60 \pm 0.08$ & $0.57 \pm 0.08$ \\
\hline
\end{tabular}

${ }^{n s}$ Non-significant

The statistical analysis results showed that the milk consumption was not significantly different between Etawah Grade and Etawah Grade x Bligon kids. It could be influenced by the milk production of does and the suckling frequency by the kids. The feed and nutrients consumed by both does were similar and then affected their milk production. The suckling frequency of kids was also similar, namely two times in the morning and evening with a duration of 15-30 minutes. The average milk consumption in this study was lowers when compared to the research results from Budisatria et al [8], who reported the milk consumption of PE goats with a single birth type, which ranged from 737 to 782 $\mathrm{g} /$ head/day. Mahmilia and Doloksaribu [15] stated that single birth kids consumed more milk than twins. The single birth and weaned kids for 60 days had a higher average milk consumption of $785 \mathrm{~g} / \mathrm{head} / \mathrm{day}$. The mothering ability of the goat can influence milk consumption. The goat may produce milk in high quantities, but if the mothering ability was poor, then the amount of milk consumption by the kids will be less than the goat with the good mothering ability [8]. Based on Kaleka and Haryadi [16], PE goats could produce 1-3 L of milk, while Bligon goats can only produce $1.5 \mathrm{~L}$.

\section{CONCLUSSION}

Based on the results, it is concluded that the growth of Etawah Grade and Etawah Grade x Bligon kids during the pre-weaning period was similar.

\section{AUTHORS' CONTRIBUTIONS}

IGSB led the study, IGSB and NN supervised the study, ATW and RWS performed the field study, BAA analyzed the data and created the manuscript. All the authors have approved the final manuscript.

\section{ACKNOWLEDGMENTS}

Thanks to the Directorate General of Higher Education, Ministry of Education and Culture of the Republic of Indonesia for funding this study with grant no. 6/E1/KP.PTNBH/2021 and contract no. 2196/UN1/DITLIT/DIT-LIT/ 2021). 


\section{REFERENCES}

[1] Direktorat Jenderal Peternakan dan Kesehatan Hewan, Statistik Peternakan dan Kesehatan Hewan, Kementerian Pertanian, Jakarta, 2018

[2] I.G.S. Budisatria, H.M.J. Udo, Goat-based aid programme in Central Java: An effective intervention for the poor and vulnerable?, Small Rumin. Res. 109 (2013) 72-78. DOI: http://dx.doi.org/10.1016/j.smallrumres.2012.07. 019

[3] S. Pakpahan, W.T. Artama, R. Widayanti, I.G.S. Suparta, Genetic Variations and the Origin of Native Indonesian Goat Breeds Based on mtDNA D-Loop Sequences, Asian J. Anim. Sci. 9(6) (2015) 341-350. DOI: http://dx.doi.org/10.3923/ajas.2015.341.350

[4] I.G.S. Budisatria, Panjono, N. Ngadiyono, B.A. Atmoko, The Productivity Comparison Between Bligon and Kejobong Goats in Indonesia, Based from On-Farm and On-Station Research J. Anim. Heal. Prod. 9(3) (2021) 262-270. DOI: http://dx.doi.org/10.17582/journal.jahp/2021/9.3. $\underline{262.270}$

[5] Rahmawati, R.D., B.A. Atmoko., I.G.S. Budisatria., N. Ngadiyono and Panjono, 2022. Exterior characteristics and body measurements of Bligon goat on the different agro-ecological zones in Bantul District, Yogyakarta, Indonesia. Biodiversitas. 23(1) (2022) 143-150. DOI: http://dx.doi.org/10.13507/biodiv/d230118

[6] Soeparno, Ilmu dan Teknologi Daging, Gadjah Mada University Press, Yogyakarta, 2005.

[7] M. Syahirah, K. Mat, N. Rusli, C. Hasnita, Preliminary study on birth weight and preweaning growth pattern in crossed Boer kids, J. Trop. Resour. Sustain. Sci 4(1) (2016) 6-9.

[8] I.G.S. Budisatria, D. Maharani, Panjono, A. Ibrahim, Kambing Peranakan Etawah: Kepala Hitam atau Cokelat?, Gadjah Mada University Press, Yogyakarta, 2018.

[9] I.G.S. Budisatria, H.M.J. Udo, C.H.A.M. Eilers, E. Baliarti, A.J. Van Der Zijpp, Preferences for sheep or goats in Indonesia, Small Rumin. Res. 88 (2010) 16-22.

DOI: http://dx.doi.org/10.1016/j.smallrumres.2009.11. $\underline{002}$

[10] N. Zurahmah, Observation of growth the Peranakan Etawah goat in intensive maintenance in Manokwari Regency, J. Ilmu Peternak. dan Vet. Trop. 8(2) (2018) 45-50. DOI: https://doi.org/10.30862/jipvet.v8i2.16

[11] T.S.M. Widi, E. Baliarti, F. Ariyanti, N. Ngadiyono, I.G.S. Budisatria, Panjono, M.D.E. Yulianto, Productivity of pre-weaning kids under smallholder production system by Introduction of superior bucks in Gunungkidul District, J. Sain Vet. 34(2) (2016) 251-258. DOI: https://doi.org/10.22146/jsv.27568

[12] A. Destomo, M. Syawal, A. Batubara, Kemampuan Reproduksi Induk dan Pertumbuhan Anak Kambing Peranakan Etawah, Gembrong, dan Kosta J. Peternak. 17(1) (2020) 31-38. DOI: http://dx.doi.org/10.24014/jupet.v17i1:7692

[13] A. Ibrahim, W.T. Artama, I.G.S. Budisatria, R. Yuniawan, B.A. Atmoko, R. Widayanti, Regression model analysis for prediction of body weight from body measurements in female Batur sheep of Banjarnegara District, Indonesia, Biodiversitas 22(7) (2021) 2723-2730. DOI: http://dx.doi.org/10.13057/biodiv/d220721

[14] R. Browning, M.L. Leite-Browning, Birth to weaning kid traits from a complete diallel of Boer, Kiko, and Spanish meat goat breeds semiintensively managed, J. Anim. Sci. 89(9) (2011) 2696-2707.

DOI: http://dx.doi.org/10.2527/jas.2011-3865

[15] F. Mahmilia, M. Doloksaribu, Relative superiority of Boer $\mathrm{x}$ Kacang at pre-weaning, JITV 15(2) (2010) 124-130. DOI: https://dx.doi.org/10.14334/jitv.v15i2.650

[16] K. Kaleka, N. Haryadi, Seri Peternakan Modern Kambing Perah. Arcita. Surakarta. PT. Arcita, Surakarta. 2013. 